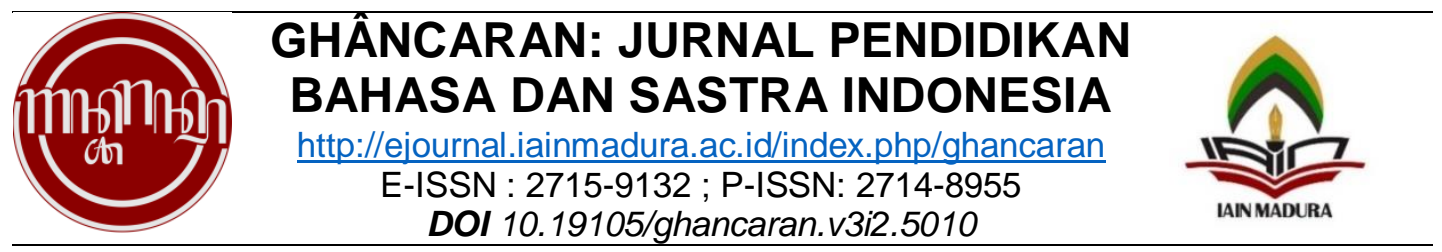

\title{
Efektivitas Model Blended Learning Terhadap Pemahaman Menulis Cerpen dalam Pembelajaran Daring
}

\author{
Awaliyah Rohmatul ${ }^{*}$, Mochamad Arifin Alatas** \\ *Pendidikan Bahasa Indonesia,Universitas Billfath Lamongan \\ **Tadris Bahasa Indonesia, IAIN Madura \\ Alamat Surel : rohmatulawalia853@gmail.com; marifin@iainmadura.ac.id
}

\begin{tabular}{l}
\hline \hline Keywords: \\
Blended learning; \\
writing short stories;
\end{tabular}

writing short stories online learnig.

\begin{abstract}
This research is motivated by the lack of students' understanding of the ability to write short stories. This study aims to see the effectiveness of the blended learning model on the understanding of short story writing in online learning carried out in class XI SMA Darul Ulum KepohbaruBojonegoro. This research method is a quantitative research method with a descriptive approach. The technique used in this research is the distribution of questionnaires and interviews. The data obtained to see the effectiveness is through student learning outcomes to write short stories and student response questionnaires about the blended learning model. The research data were then analyzed using the normality test and linearity test. From the results of the research, it is known that the normality test value of the results of writing short stories has a significance value of $0.026>0.05$, while the results of student responses have a significance value of $0.679>0.05$. Then. In the linearity test, the significance value is $0.129>0.05$, meaning that the blended learning model is effectively used for understanding short story writing.
\end{abstract}

\section{Kata Kunci:}

Blended learning; menulis cerpen; pembelajaran daring.

\section{Abstrak:}

Penelitian ini dilatarbelakangi dengan adanya kurangnya pemahaman siswa terhadap kemampuan materi menulis cerpen. Penelitian ini bertujuan untuk melihat efektivitas model blended learning terhadap pemahaman menulis cerpen dalam pembelajaran daring yang dilakukan pada siswa kelas XI SMA Darul Ulum Kepohbaru Bojonegoro. Penelitian ini menggunakan metode kuantitatif dengan pendekatan deskriptif. Teknik yang digunakan dalam penelitian ini adalah penyebaran angket dan wawancara. Data yang diperoleh untuk melihat keefektifan melalui hasil belajar siswa menulis cerpen dan angket respon siswa tentang tentang model blended learning. Data penelitian dianalisis menggunakan uji normlitas dan uji linearitas. Dari hasil peneilitian diketahui bahwa nilai uji normalitas dari hasil menulis cerpen signifikansinya adalah $0,026>0,05$, sedangkan dari hasil respon siswa nilai signifikansi $0,679>0,05$. Dalam uji linieritas nilai signifikansinya $0,129>0,05$, artinya model blended learning efektif digunakan terhadap pemahaman menulis cerpen pada siswa.

\begin{tabular}{ccc}
\hline Terkirim : 8 Oktober 2021 & ; Revisi: 6 Desember 2021 & ; Diterima: 28 Januari 2022 \\
\hline OGhâncaran: Jurnal Pendidikan Bahasa dan Sastra Indonesia \\
Tadris Bahasa Indonesia \\
Institut Agama Islam Negeri Madura, Indonesia
\end{tabular}




\section{PENDAHULUAN}

Pembelajaran dalam jaringan (daring/online) merupakan pembelajaran yang dilaksanakan dengan memanfaakan media jaringan (online) (Lubis et al., 2021; Panditung, 2020). Jaringan online tersebut adalah pemanfaatan atau gabungan antara teknologi dan internet. Sofyana dan Rozaq (2019) mengungkapkan prinsip pembelajaran daring atau jarak jauh yakni menggunakan aplikasi tertentu yang dimanfaatkan untuk pembelajaran, sehinga tidak bertemu atau bertatap muka langsung. Hal tersebut untuk miningkatkan layanan dan mutu pembelejaran dalam jaringan. Selain itu, dengan media internet juga dapat dijangkau pembelajar dimanapun dan kapanpun (Pohan, 2020; Sanjaya, 2020).

Berdasarkan pengamatan yang dilakukan, ditemukan kesulitan yang dialami oleh siswa yang berada di sekolah SMA Darul Ulum Kepohbaru. Hal ini dibuktikan dari hasil wawancara terhadap master dan peserta didik. Pertama, siswa merasa sulit untuk memahami dan menerima materi dari master. Kedua, hasil belajar siswa dalam menulis teks belum maksimal karena siswa masih sulit dalam mengembangkan ide dan menggambarkan tema. Ketiga, kurangnya minat siswa dalam menulis cerpen. Keempat, siswa kesulitan dalam pemilihan kosa individualized organization bahasa Indonesia baku. Kelima, master memiliki jadwal yang padat sehingga kelas kadangkadang ditinggal tanpa adanya master pengganti atau tugas pengganti. Hal tersebut membuat siswa tidak belajar, tidak terkontrol dan bermain di luar kelas. Keenam, adanya keterbatasan waktu dan interaksi pembelajaran. Waktu pembelajaran semakin singkat sehingga materi dan interaksi siswapun juga semakin terbatas.

Berdasarkan kendala-kendala yang dirasakan siswa, maka perlu diadakan upaya perbaikan dalam expositions pembelajaran. Oleh karena itu, pembelajaran menulis cerita di kelas memerlukan inovasi dan kreasi baru. Salah satu inovasi baru tersebut, yaitu model pembelajaran berbasis blended learning.

Model pembelajaran blended learning adalah penggabungan antara pembelajaran langsung dan jarak jauh. Lebih rinci lagi, Blended learning merupakan pendidikan yang mencampurkan pada 2 aspek yakni tatap muka langsung serta pendidikan berbasis pc (offline dan online) (Caner 2012; Fitriah \& Fitriani 2017; Stacey \& Gerbic 2009). Pendidikan blended learning bertujuan guna membagikan peluang untuk pelajar supaya bisa belajar dengan mandiri, berkepanjangan, serta tumbuh selama hayat (Dwiyogo 2018; Valiathan 2002). Media pembelajarannyapun juga lebih bervariasi. Media pembelajaran meliputi audio, visual, dan audio-visual (Alatas, 2019). Media pembelajaran tidak terbatas pada media pembelajaran visual saja (huruf, gambar, dan 
foto). Media pembelajaran dapat dikreasikan dengan media audio-visual (grafik, audio, video, animasi, dan film). Model blended learning diperlukan dalam proses pendidikan diharapkan dapat membantu partisipan didik dalam belajar.

Sementara itu, Sari (2012) mengartikan bahwa blended learning adalah kombinasi atau pencampuran. Kombinasi tersebut adalah mengombinasikan bentuk atau pola satu dengan yang lainnya. Istilah lain dari blended learning yang sering dikenal adalah blended blended e-learning, hybrid learning, melted learning dan mixed learning (He, 2010; Ranjini, 2020; Sinaga, 2019). Sebagaimana pendapat Wibowo (2019) blended learning merupakan gabungan antara kelas nyata dan kelas maya. Kelas nyata adalah kelas dengan pembelajaran langsung di kelas, sedangkan kelas maya adalah kelas yang dibuat secara online atau virtual.

Salah satu contoh pembelajaran blended learning adalah penggabungan pembelajaran langsung dengan aplikasi Whatsapp. Media sosial Whatsapp dapat digunakan dalam pembelajaran (Rachmayanti \& Alatas, 2021). Selain media sosial Whatsapp juga aplikasi Edmodo juga dapat digunakan dalam pembelajaran (Rachmayanti \& Alatas, 2020). Blended Learning juga dapat melalui teknik yang digunakan. Hal tersebut misalkan penggunaan teknik modelling digital dalam pembelajaran (Alatas \& Albaburrahim, 2021). Berdasarkan penelitian tersebut penggunaan blended learning dapat digunakan dalam pembelajaran.

Alasan digunakannya blended learning adalah membiasakan peserta didik menggunakan media sosial untuk hal-hal positif. Blended learning juga dapat meningkatkan interaksi antara peserta didik. Sari (2012) juga menjelaskan bahwa blended learning mampu menerobos ruang dan waktu, tidak terbatas secara psikologis, siswa dapat beragumentasi sehingga meningkatkan berpikir kritis siswa, meningkatkan penguasaan materi. Dengan demikian, blended learning tersebut dapat memperbaiki kualitas pembelajaran.

Penelitian terdahulu yang mendasari penelitian ini yakni dilakukan oleh Onta (2018) dengan judul "Efektivitas Penerapan Model Blended Learning dengan Menggunakan Median Pembelajaran Quipper School di Tinjau dari Motivasi Belajar dan Hasil Belajar Siswa Kelas X TKJ-A SMA Asisi Jakarta Tahun Ajaran 2017/2018”. Hasil penelitian tersebut adalah model blended learning dengan Quipper School efektif diterapkan dalam kegiatan belajar mengajar. Selain itu, siswa menunjukkan tinggkat motivasi yang baik. Hal tersebut ditunjukkan dengan terdapat 11 siswa (78.58\%) mempunyai motivasi baik. Selain itu, hasil belajar siswapun juga menunjukkan hasil yang baik. Hal tersebut terlihat pada tingkat presentase siswa yang lulus KKM yakni 
14.29\%. Dengan demikian dapat disimpulkan bahwa model pembelajaran blended learning efektif dari segi motivasi dan hasil belajar siswa.

Penelitian sebelumnya juga dilakukan oleh Setiawan \& Aden (2020) yang berjudul "Efektifitas Penerapan Blended Learning dalam Upaya Meningkatkan Kemampuan Akademik Mahasiswa Melalui Jejaring Schoology di Masa Pandemi Covid-19". Berdasarkan penelitian tersebut disimpulkan bahwa kemampuan akademik mahasiswa mampu diingkatkan dengan model pembelajaran blended learning. Hal tersebut dibuktikan dengan nilai hitung > tabel yang bermakna terdapat pebedaan signifikan antara kelas eksperiman dan kontrol. Adapun rinciannya adalah nilai tabel 2,030 sedangkan nilai hitung 8,8367.

Adapun persamaan penelitian ini dengan penelitian terdahulu adalah sama-sama menggunakan metode pembelajaran blended learning. Adapun perbedaannya terletak pada materi dan media yang digunakan. Tujuan penelitian ini adalah untuk mengetahui tingkat keefektifan model blended learning terhadap pemahaman menulis cerpen siswa. Alasan penting digunakannya model pembelajaran ini agar siswa tetap bisa melakukan pembelajaran walau dalam kondisi pandemi. Dengan digunakannya model blended learning ini dikarenakan kelebihannya dapat membantu peneliti meningkatkan pemahaman menulis cerpen dalam pembelajaran daring terhadap siswa.

\section{METODE}

Metode penelitian ini adalah metode penelitian kuantitatif. Pendekatan dalam penelitian ini adalah deskriptif. Metode yang digunakan dalam penelitian ini bersifat nyata, empiris, terukur, rasional, objektif, dan sistematis. Sehingga dapat disebut sebagai metode ilmiah atau scientifik. Selain itu, metode penelitian ini juga menemukan hal-hal baru dan mengembangkannya menjadi ilmu pengetahuan dan teknologi. Oleh karena itu metode tersebut juga disebut dengan metode discovery. Metode tersebut dipilih karena penelitian ini memiliki data angka-angka yang dianalisis secara statistik (Hartas, 2015; Sugiyono, 2015).

Penelitian ini memiliki dua data yang meliputi data hasil belajar dan respon siswa. Data hasil belajar siswa berdasarkan nilai tugas dan tes, sedangkan data respon siswa berdasarkan angket yang diberikan kepada siswa. Adapun jumlah siswa sebanyak 36 siswa. Teknik pengumpulan data melalui pemberian tugas, menyebaran angket, dan wawancara terhadap siswa. Instrumen penelitian ini meliputi angket dan pedoman wawancara. Data tersebut diinterpretasikan berdasarkan teori model 
pembelajaran blended learning secara deskriptif. Analisis data dalam penelitian ini yani berupa nilai persentase dengan skala likert, uji normalitas, dan uji linearitas.

\section{HASIL DAN PEMBAHASAN}

\section{Data Hasil Pembelajaran dengan Model Blended Learning}

Informasi hasil belajar siswa dengan model blended learning diawali dengan peneliti mengantarkan kompetensi yang hendak dicapai. Peneliti juga menginformasikan bahwa pendidikan model blended learning ialah model pendidikan campuran antara pendidikan sinkronus serta asinkronus. Dalam riset ini pendidikan mencoba sebanyak 4 kali pertemuan dengan model pendidikan sinkronus dan asinkronus. Pendidikan sinkronus ialah pendidikan berbasis daring (online) buat platform yang diseleksi ialah berbentuk aplikasi classroom, di mana pendidikan serta pemberian model hendak diunggah dalam aplikasi tersebut. Siswa dapat belajar dialog lewat jaringan online. Tidak lepas dari itu, peneliti senantiasa memantau aktivitas siswa di pembelajaran online. Berikutnya dalam pendidikan asinkronus (tatap muka) dicoba pendalaman modul yang sudah dipelajari dalam pendidikan online. Peneliti mengantarkan uraian menimpa modul menulis cerpen dengan tatap muka (offline), Setelah peneliti bertanya kepada siswa apakah siswa menguasai modul menulis cerpen serta siswa menanggapi kalau mereka paham, setelah itu membagikan tugas membuat cerpen.

Siswa diberikan kebebasan dalam menulis cerpen (offline). Adapun langkahlangkah menulis cerpen meliputi (1) memastikan tema, (2) memastikan alur cerita, (3) penokohan, (4) memastikan tempat serta waktu, (5) menulis garis besar cerita, (6) mencermati faktor intrinsik dan ekstrinsik, (7) menulis judul. Selanjutnya menyampaikan kembali lewat pendidikan sinkronus (online) bahwa hasil menulis cerpen wajib dikumpulkan keesokan harinya. Setelah penerapan proses pendidikan berakhir serta tugas telah dikumpulkan seluruhnya. Hasil belajar siswa tersebut selanjutnya dianalisis. Informasi hasil belajar merupakan nilai uji menulis cerpen dari kelas XI SMA Darul Ulum yang dikerjakan secara perorangan oleh siswa. Informasi nilai siswa didapat dari kriteria evaluasi yang sudah dicoba oleh peneliti dilihat dari lembar penilaian belajar siswa. Hasil dari belajar siswa kelas XI SMA Darul Ulum dengan model blended learning bisa dilihat pada tabel berikut. 


\begin{tabular}{|c|c|c|c|}
\hline & & $\begin{array}{c}\text { Hasil Belajar } \\
\text { Menulis Cerpen } \\
\text { Siswa }\end{array}$ & $\begin{array}{l}\text { Hasil Respon } \\
\text { Angket Siswa }\end{array}$ \\
\hline $\mathrm{N}$ & & 36 & 36 \\
\hline \multirow[t]{2}{*}{ Normal Parameters ${ }^{a}$} & Mean & 75.2778 & 41.1667 \\
\hline & Std. Deviation & 4.84391 & 5.00571 \\
\hline \multirow[t]{3}{*}{ Most Extreme Differences } & Absolute & .245 & .120 \\
\hline & Positive & .245 & .120 \\
\hline & Negative & -.138 & -.076 \\
\hline Kolmogorov-Smirnov Z & & 1.471 & .720 \\
\hline Asymp. Sig. (2-tailed) & & .026 & .679 \\
\hline
\end{tabular}

Test distribution is Normal.

Tabel 1. Hasil Uji Normalitas One-Sample Kolmogorov-Smirnov Test

Berdasarkan tabel tersebut, terlihat hasil uji normalitas yakni nilai signifikansi hasil belajar siswa menulis cerpen adalah 0,026>0,05. Sedangkan nilai signifikansi hasil angket siswa adalah 0,679>0,05. Angka-angka tersebut menunjukkan bahwa nilai berdistribusi normal. Selain itu juga dilakukan uji linieritas. Hasil uji linieritas bisa dilihat pada tabel berikut.

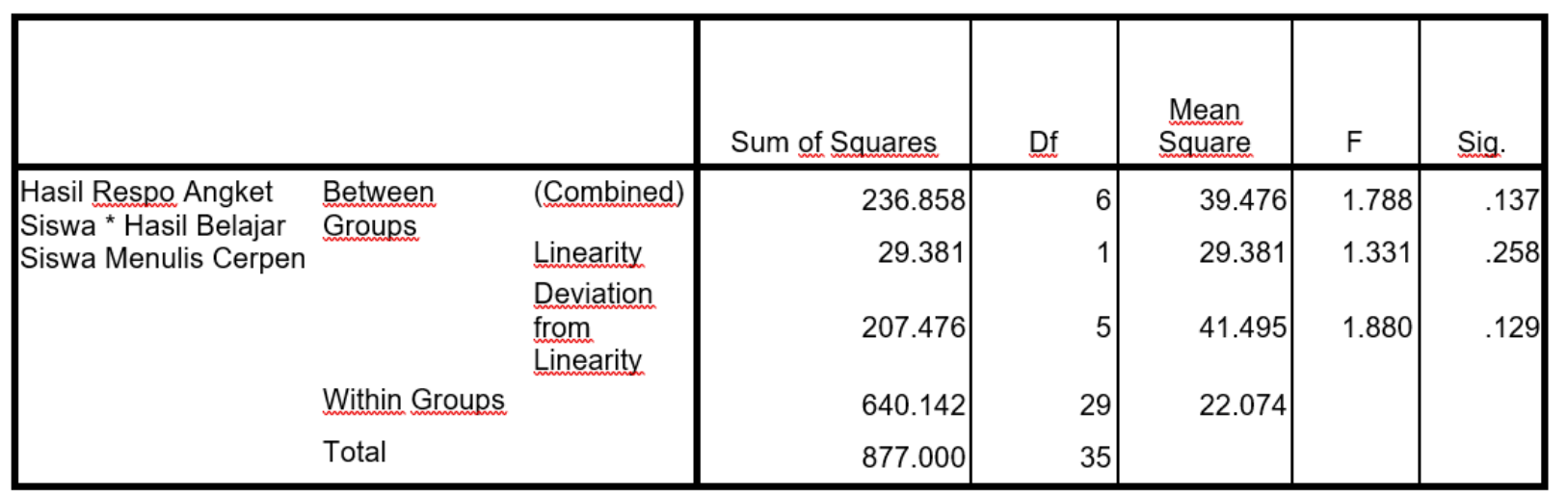

Tabel 2. Hasil Uji Linearitas

Berdasarkan tabel tersebut, dapat dilihat bahwa signifikansi pada Devation Of Linerity lebih dari 0,05 yaitu $(0,129>0,05)$. Angka-angka tersebut dapat dimaknai bahwa terdapat hubungan yang linier antara variabel $X$ (Hasil Menulis Cerpen) dengan variable $Y$ (Hasil respon angket siswa mengenai blended learning).

\section{Data Hasil Angket}

Angket tanggapan siswa terdiri atas empat belas pertanyaan. Masing-masing pertanyaan terdapat empat pilihan jawaban. Keempat pilihan jawaban tersebut meliputi 1. Sangat Setuju (SS), 2. Setuju (S), 3. Tidak Setuju (TS), dan Sangat Tidak Setuju (STS). Angket tersebut merupakan angket tertutup. Adapun hasi angket tersebut dapat dilihat pada tabel berikut. 


\begin{tabular}{|c|c|c|c|c|c|c|c|c|}
\hline \multirow{2}{*}{ No } & \multirow{2}{*}{ Pernyataan } & \multirow{2}{*}{$\begin{array}{l}\text { Jenis } \\
\text { Pernyataan }\end{array}$} & \multicolumn{4}{|c|}{ Frekuensi } & \multirow{2}{*}{ Skor } & \multirow{2}{*}{ Persentase } \\
\hline & & & SS & $\mathbf{S}$ & TS & STS & & \\
\hline 1 & $\begin{array}{lr}\text { Dengan } & \text { model } \\
\text { pembelajaran blended } & \text { bemingan } \\
\text { learning memudahkan } \\
\text { saya dalam belajar } \\
\text { menulis cerpen }\end{array}$ & + & 9 & 15 & 8 & 4 & 101 & $70,14 \%$ \\
\hline 2 & $\begin{array}{l}\text { Saya tertarik dengan } \\
\text { model pembelajaran } \\
\text { blended learning }\end{array}$ & + & 7 & 15 & 9 & 5 & 95 & $65,97 \%$ \\
\hline 3 & $\begin{array}{ll}\text { Saya } & \text { senang } \\
\text { menggunakan } & \\
\text { pemelajaran } & \text { blended } \\
\text { learning. } & \end{array}$ & + & 6 & 24 & 6 & 0 & 108 & $75 \%$ \\
\hline 4 & $\begin{array}{lr}\text { Pembelajaran online } \\
\text { membantu saya } \\
\text { memahami materi } \\
\text { menulis cerpen yang } \\
\text { saya pelajari secara lebih } \\
\text { mendalam }\end{array}$ & + & 15 & 15 & 6 & 0 & 132 & $91,66 \%$ \\
\hline 5 & $\begin{array}{l}\text { Dengan pembelajaran } \\
\text { online saya menemukan } \\
\text { pengetahuan- } \\
\text { pengetahuan baru yang } \\
\text { belum saya dapat dari } \\
\text { pembelajaran di kelas. }\end{array}$ & + & 22 & 14 & 0 & 0 & 130 & $90,27 \%$ \\
\hline 6 & $\begin{array}{l}\text { Apabila mengalami } \\
\text { kesulitan, saya hanya } \\
\text { perlu menugunggu } \\
\text { pembahasan jawaban } \\
\text { soal yang diberikan guru } \\
\text { dari pada harus mencari } \\
\text { solusinya dari sumber } \\
\text { internet (online). }\end{array}$ & - & 12 & 9 & 7 & 8 & 97 & $67,36 \%$ \\
\hline 7 & $\begin{array}{l}\text { Saya tidak perlu rutin } \\
\text { untuk } \\
\text { website pengunjungi } \\
\text { atau } \\
\text { pembelajaran online }\end{array}$ & - & 2 & 12 & 19 & 3 & 104 & $72,22 \%$ \\
\hline 8 & $\begin{array}{l}\text { Pembelajaran online } \\
\text { diadakan hanya semata- }\end{array}$ & - & 2 & 12 & 20 & 2 & 80 & $55,55 \%$ \\
\hline
\end{tabular}




\begin{tabular}{|c|c|c|c|c|c|c|c|c|}
\hline & $\begin{array}{l}\text { mata untuk mendapatkan } \\
\text { nilai tambah dari guru }\end{array}$ & & & & & & & \\
\hline 9 & $\begin{array}{l}\text { Karena bisa saling } \\
\text { berinteraksi baik dengan } \\
\text { teman dan guru tanpa } \\
\text { rasa segan membuat } \\
\text { saya antusias dalam } \\
\text { mengikuti pembelajaran } \\
\text { blended learning. }\end{array}$ & + & 6 & 27 & 3 & 0 & 100 & $69,44 \%$ \\
\hline 10 & $\begin{array}{l}\text { Saya beranggapan } \\
\text { bahwa guru saya tidak } \\
\text { akan } \\
\text { mempermasalahkan jika } \\
\text { saya tidak mengikuti sesi } \\
\text { pembelajaran menulis } \\
\text { cerpen secara blended } \\
\text { learning. }\end{array}$ & + & 5 & 7 & 22 & 2 & 87 & $60,41 \%$ \\
\hline 11 & $\begin{array}{l}\text { Saya mampu mendata } \\
\text { peristiwa yang saya alami } \\
\text { dalam menulis cerpen }\end{array}$ & + & 8 & 27 & 1 & 0 & 115 & $79,86 \%$ \\
\hline 12 & $\begin{array}{l}\text { Saya mampu } \\
\text { menentukan konflik yang } \\
\text { ada dalam peristiwa yang } \\
\text { dipilih dalam menulis } \\
\text { cerpen }\end{array}$ & + & 6 & 29 & 1 & 0 & 110 & $76,38 \%$ \\
\hline 13 & $\begin{array}{l}\text { Saya mempu } \\
\text { menentukan alur cerita }\end{array}$ & + & 10 & 25 & 0 & 0 & 115 & $79,86 \%$ \\
\hline 14 & $\begin{array}{l}\text { Saya mampu memahami } \\
\text { penjelasan guru tentang } \\
\text { menulis cerpen }\end{array}$ & + & 10 & 27 & 0 & 0 & 121 & $84,1 \%$ \\
\hline \multicolumn{7}{|c|}{ Jumlah } & $\begin{array}{l}1.38 \\
0\end{array}$ & $74,14 \%$ \\
\hline
\end{tabular}

Tabel 3. Tanggapan Siswa Mengenai Pembelajaran Model Blended Learning dalam Pemahaman Menulis Cerpen

Berdasarkan tabel tanggapan tersebut diketahui bahwa (1) Pembelajaran dengan model blended learning dapat memudahkan siswa dalam belajar menulis cerpen. Adapun presentasenya mencapai $70.14 \%$. Pernyataan berikutnya (2) sebesar $65.97 \%$ siswa tertarik terhadap pembelajaran dengan model blended learning. Selain itu juga (3) siswa yang senang terhadap pembelajaran dengan model blended learning sebesar 75\%. Bahkan (4) hampir $91.66 \%$ siswa dapat mendalami materi dari pembelajaran 
online. Kemudian yang ke (5) sebesar $90.27 \%$ siswa mampu menemukan pengetahuan baru yang tidak ditemukan pada pembelajaran di kelas. Namun (6) apabia siswa mengalami kesulitan sebesar $67.36 \%$ menunggu solusi dari guru daripada mencari secara mandiri di internet. (7) Sebesar $72.22 \%$ siswa tidak perlu mengunjungi website secara rutin. Kemudian yang ke (8) sebesar $55.55 \%$ siswa menganggap pembelejaran online hanya semata-mata ingin mencari nilai dari guru. (9) Pembelajaran online ini juga dapat membuat interaksi dengan baik sehingga siswa antusias dalam pembelejaran sebesar $69.44 \%$. kemudian (10) sebesar $60.41 \%$ beranggapan bahwa guru tidak akan mempersalahkan siswa jika tidak mengikuti pembelajaran. (11) siswa juga mampu mendata peristiwa yang dia alami sebesar 60.41\%. (12) Sebagian besar siswa mampu menemukan permasalahan atau konflik dalam cerpen dengan persentase sebesar 76.38\%. Tidak hanya itu, (13) sebesar 79.86\% siswa mampu menentukan alur cerita dalam cerpen. Kemudian yang terkahir (14) sebesar $84.1 \%$ siswa mampu memahami penjelasan dari guru. Dengan demikian dapat disimpulkan bahwa nilai persentase dari tabel di atas dengan overall keseluruhan persentase respon tanggapan siswa rata-rata sebesar $74,14 \%$.

\section{Efektivitas Pembelajaran}

Tingkat efektivitas pembelajaran model blended learning dapat dilihat pada data hasil belajar dan angket siswa. Hasil belajar siswa tersebut berdasarkan tugas dan tes yang telah dilaksanakan. Sedangkan angket tersebut merupakan angket tertutup berisikan empat belas pertanyaan tanggapan terhadap pembelajaran blended learning. Efektivitas pembelajaran diuji dengan uji normalitas dan uji linieritas.

Berdasarkan hasil uji normalitas, terlihat hasil uji normalitas yakni nilai signifikansi hasil belajar siswa menulis cerpen adalah 0,026>0,05. Sedangkan nilai signifikansi hasil angket siswa adalah 0,679>0,05. Dengan demikian dapat disimpulkan bahwa nilai berdistribusi normal. Sedangkan signifikansi pada Devation Of Linerity lebih dari 0,05 yaitu $(0,129>0,05)$. Dengan demikian dapat disimpulkan bahwa terdapat hubungan yang linier antara variabel $X$ (Hasil Menulis Cerpen) dengan variable $Y$ (Hasil respon angket siswa mengenai blended learning).

Berdasarkan data penelitian ini, diketahui bahwa pembelajaran pemahamanan menulis cerpen dengan model blended learning pada siswa kelas XI SMA Darul Ulum Kepohbaru efektif untuk digunakan. Melihat dari data tabel 1 yang telah dipaparkan bahwa signifikasi sebesar 0,26>0.05 siswa mampu belajar dengan menggunakan model blended learning. Sementara itu, pembelajaran secara langsung yang telah 
dilakukan di kelas XI SMA Darul Ulum Kepohbaru juga efektif digunakan berdasarkan data hasil belajar dan respon siswa.

Pembelajaran langsung memiliki kelebihan masing-masing siswa dapat belajar dan berkembang baik secara akademik dan non akademik. Selain itu pembelajaran langsung juga mendukung siswa yang di bawah rata-rata belajar sehingga dapat meningkatkan nilainya. Kelebihan berikutnya adalah mudahnya memahami penjelansan sehingga mengurangi adanya salah tafsir. Namun demikian, pembelajaran langsung tidak dapat diterapkan sepenuhnya pada pandemi covid-19.

Angket tanggapan siswa terdiri atas empat belas pertanyaan. Masing-masing pertanyaan terdapat empat pilihan jawaban. Keempat pilihan jawaban tersebut meliputi 1. Sangat Setuju (SS), 2. Setuju (S), 3. Tidak Setuju (TS), dan Sangat Tidak Setuju (STS). Angket tersebut merupakan angket tertutup. Adapun nilai maksimal pada masing-masing pertanyaan adalah empat dan nilai total adalah lima puluh enam.

Berdasarkan angket tanggapan siswa diketahui nilai persentase pada masingmasing pertanyaan. Nilai persentase yang paling tinggi adalah $91.66 \%$ yang menyatakan bahwa siswa mampu memahami materi menulis cerpen dengan pembelajaran online. Sedangkan nilai paling rendah adalah 55.55\% yang menyatakan bahwa pembelajaran daring hanya untuk nilai tambahan saja. Persentase total yang telah didapatkan adalah $74.12 \%$ yang termasuk kategori tinggi. Dengan demikian dapat disimpulkan bahwa rata-rata siswa menyukai pemelajaran blended learning dengan penggunaan classroom. Namun demikian, siswa juga masih memerlukan pembelajaran langsung. Siswa beranggapan bahwa pembelajaran langsung lebih jelas dalam memahami isi materi. Oleh karena itu, pembelajaran online dan offline sebaiknya dilaksanakan secara seimbang.

Hasil analisis yang telah dilakukan, penggunaan model pembelajaran blended learning terhadap pemahaman menulis cerpen dalam pembelajaran daring pada siswa kelas XI SMA Darul Ulum Kepohbaru menunjukkan data normal dan linear. Nilai signifikansi yang diperoleh, yaitu siswa mampu dan memahami materi menulis cerpen $0,026>0,05$ sedangkan hasil angket respon siswa nilai signifikansi 0,679>0,05. Data menunjukkan siswa dapat memahami dan mampu menulis cerpen dengan menggunakan pembelajaran model blended learning. Dalam kondisi saat ini, guru dapat memanfaatkan berbagai macam platform media pembelajaran daring. Blended learning menjadi salah satu model pembelajaran yang mengkombinasikan pembelajaran tatap muka dan dalam jaringan bisa digunakan dalam pembelajaran jarak jauh. 


\section{SIMPULAN}

Efektivitas pembelajaran blended learning terhadap pemahaman menulis cerpen dalam pembelajaran daring pada siswa kelas XI SMA Darul Ulum Kepohbaru yang ditinjau dari hasil belajar siswa dapat dikatakan efektif. Hal tersebut berdasarkan analisis uji normalitas yang telah dilakukan. Data hasil belajar siswa menulis cerpen $0,026>0,05$, sedangkan hasil angket respon siswa nilai signifikansi 0,679>0,05. Dari uji linearitas nilai signifikansi pada Devation Of Linerity lebih dari 0,05 $(0,129>0,05)$. Efektivitas blended learning ditinjau dari respon angket siswa dapat dikatakan efektif dengan persentase tertinggi sebesar $91.66 \%$ yang menyatakan pembelajaran online membantu siswa memahami materi menulis cerpen yang siswa pelajari secara lebih mendalam. Persentase terendah sebesar 55,55\% pada pernyataan mengenai pembelajaran online diadakan hanya semata-mata untuk mendapatkan nilai tambah dari guru. Berdasarkan presentase total sebesar $74,12 \%$ yang termasuk tinggi dapat disimpulkan bahwa siswa sudah memiliki ketertarikan terhadap model blended learning dengan menggukan aplikasi classroom. Walaupun demikian, pembelajaran tetap membutuhkan pembelajaran langsung atau tatap muka di kelas. Hal tersebut karena siswa beranggapan materi akan lebih mudah dipahami jika pembelajaran langsung atau tatap muka.

\section{DAFTAR RUJUKAN}

Alatas, M. A. (2019). Media Pembelajaran Bahasa Indonesia (H. A. Ghazali (ed.)). CV. Madza Media.

Alatas, M. A., \& Albaburrahim. (2021). Penggunaan Teknik Modelling Digital untuk Meningkatkan Kemampuan Membaca Puisi. Jurnal Ibriez: Jurnal Kependidikan Dasar Islam Berbasis Sains, 6(2), 177-192.

Caner, M. (2012). The definition of blended learning in higher education. Blended Learning Environments for Adults: Evaluations and Frameworks, 19-34.

Dwiyogo, W. D. (2018). Pembelajaran Berbasis Blended Learning. PT Raja Grafindo Persada.

Fitriah, F., \& Fitriani, S. S. (2017). Analisis Tindak Tutur dalam Novel Marwah di Ujung Bara Karya R.H. Fitriadi. Master Bahasa, 5(1), 51-62.

Hartas, D. (2015). Educational research and inquiry: Qualitative and quantitative approaches. Bloomsbury Publishing.

He, K. (2010). Hybrid Learning and New Development of "IT in Education" Theory. International Conference on Hybrid Learning, 513-531.

Lubis, H. Z., Eriska, P., Bismala, L., Arifin, M., Hidayat, F. P., IKom, M., Rudianto, S., Harfiani, R., Nasution, D. K., \& Panggabean, S. (2021). Inovasi Pembelajaran di Masa Merdeka BelajarKampus Merdeka (New Normal); Antara Peluang dan Tantangan (Vol. 1). umsu press.

Onta, M. R. (2018). Efektivitas Penerapan Model Blended Learning dengan Menggunakan Media Pembelajaran Quipper School Ditinjau dari Motivasi Belajar dan Hasil Belajar Siswa Kelas X TKJ-A SMK Asisi Jakarta Tahun Ajaran 
2017/2018. Universitas Sanata Dharma.

Panditung, A. R. (2020). Implementasi Kegiatan Pembelajaran Jarak Jauh Era Pandemi Covid-19 di Tingkat SMA. Edudikara: Jurnal Pendidikan Dan Pembelajaran, 5(4), 231-240.

Pohan, A. E. (2020). Konsep pembelajaran daring berbasis pendekatan ilmiah. Penerbit CV. Sarnu Untung.

Rachmayanti, I., \& Alatas, M. A. (2020). Implementasi Aplikasi Edmodo dalam Pembelajaran Bahasa Arab Berbasis Daring di PKPBA UIN Maulana Malik Ibrahim Malang. Kadera Bahasa, Volume 12(Nomor 2), 99-110.

Rachmayanti, I., \& Alatas, M. A. (2021). Pemanfaatan Aplikasi Whatsapp Group Sebagai Media Pembelajaran Daring Pada Masa Pandemi Covid-19. Jurnal Bio Educatio, 6(4), 68-81.

Ranjini, G. A. (2020). Blended Learning. Social Media in Teaching and Learning, 179.

Sanjaya, R. (2020). 21 Refleksi Pembelajaran Daring di Masa Darurat. SCU Knowledge Media.

Sari, M. (2012). Blended Learning, Model Pembelajaran Abad Ke-21 di Perguruan Tinggi. Ta'dib, 17(2), 126-136.

Setiawan, T. H., \& Aden, A. (2020). Efektifitas Penerapan Blended Learning dalam Mahasiswa Melalui Jejaring Schoology di Masa Pandemi Covid-19. JPMI (Jurnal Pembelajaran Matematika Inovatif ), 3(5), 493-506.

Sinaga, E. P. (2019). Blended Learning: Transisi Pembelajaran Konvensional Menuju Online.

Sofyana, L., \& Rozaq, A. (2019). Pembelajaran Daring Kombinasi Berbasis Whatsapp pada Kelas Karyawan Prodi Teknik Informatika Universitas PGRI Madiun. Jurnal Nasional Pendidikan Teknik Informatika : JANAPATI, 8(1), 81-86.

Stacey, E., \& Gerbic, P. (2009). Introduction to blended learning practices. Effective Blended Learning Practices: Evidence-Based Perspectives in ICT-Facilitated Education, 1-19.

Sugiyono. (2015). Metode Penelitian Pendidikan Pendekatan Kuantitatif, dan R\&D. Alfabeta.

Valiathan, P. (2002). Blended learning models. Learning Circuits, 3(8), 50-59.

Wibowo, N. P. (2019). Pengaruh Model Pembelajaran Blended Learning Menggunakan Aplikasi Edmodo terhadap Hasil Belajar dan Keterlibatan Siswa pada Pokok Bahasan Mata dan Kacamata untuk Siswa Kelas XI MIPA 2 SMAN 1 Ngemplak. Universitas Sanata Dharma. 